\title{
Health Effects of Particulate Air Pollution
}

\author{
Douglas W. Dockery \\ Professor of Environmental Epidemiology, Departments of Environmental Health and \\ Epidemiology, Harvard School of Public Health
}

In 1979 the American Journal of Epidemiology devoted an entire issue to a review of the health effects of particulate air pollution. The authors, well known British epidemiologists, concluded that there was no evidence for negative health effects from particulate pollution at levels seen in the United States. 1 Yet less than 30 years later, the Environmental Protection Agency reported "Inhalation of fine particles is causally associated with premature death at concentrations near those experienced by most Americans on a daily basis."2 The United States Office of Management and Budget reported that federal regulations to control particulate air pollution were the most cost-effective regulations imposed by the US government. 3 In just one generation, a major threat to public health which some denied even existed has been confirmed, addressed by public policy, and significantly reduced, based on the foundations provided by epidemiology.

\section{What is particulate air pollution?}

In the simplest terms, particulate air pollution is anything solid or liquid suspended in the air. It includes smoke, fumes, soot, and other combustion byproducts, but also natural particles such as windblown dust, sea salt, pollen, and spores. It includes primary particles coming directly out of exhaust stacks and tailpipes, but also can include secondary particles such as sulfates and nitrates which form from condensation of vaporized materials or from the byproducts of the oxidation of gases in the atmosphere. So particulate air pollution is a mixture of contaminants from a range of sources.

Particles are characterized by their aerodynamic properties, measured as aerodynamic diameter measured in micrometers $(\mu \mathrm{m})$. In early studies in the United States particle concentrations were measured as the mass of particles collected on a filter, divided by the volume of sample drawn through the filter, that is Total Suspended Particles (TSP). In England, particle concentrations were measured by the visual blackness of particles collected on a white filter, Black Smoke or British Smoke (BS) expressed as equivalent mass concentration of a standard coal smoke.

In the mid-1980's studies of the deposition and clearance of particles in the respiratory system, along with studies of atmospheric physics and chemistry, suggested that smaller particles might be a larger part of the health threat, and that control strategies should focus on smaller particles. Inhalable particles were defined as particulate matter less than $10 \mu \mathrm{m}$ aerodynamic diameter $\left(\mathrm{PM}_{10}\right)$. In the 1990's evidence began to develop suggesting that even smaller particles, that is those less than $2.5 \mu \mathrm{m}\left(\mathrm{PM}_{2.5}\right)$, were able to penetrate into the alveolar gas-exchange regions of the lungs, and may be specifically related to health effects.

Publisher's Disclaimer: This is a PDF file of an unedited manuscript that has been accepted for publication. As a service to our customers we are providing this early version of the manuscript. The manuscript will undergo copyediting, typesetting, and review of the resulting proof before it is published in its final citable form. Please note that during the production process errors may be discovered which could affect the content, and all legal disclaimers that apply to the journal pertain. 


\section{Early Epidemiology and Regulation}

The goals of early air pollution legislation in the United States were broad and general, but called for a science-based approach to control. The 1970 Clear Air Act required identification of pollutants which "may reasonably be anticipated to endanger public health and welfare". The Act required the government to establish criteria which "accurately reflect the latest scientific knowledge useful in indicating the kind and extent of all identifiable effects on public health and welfare" (section 10842 USC 708). Based on epidemiologic analyses of air pollution episodes and cross-sectional studies of mortality and morbidity 4 , the first ambient air quality standard for particulate matter defining maximum allowable ambient concentrations of TSP was promulgated in 1971.

In the early 1970s, the EPA undertook a series of epidemiologic studies, known as the Community Health and Environmental Surveillance System [CHESS], to assess the health effects of all forms of air pollution. However, concerns were raised about the design, analyses, and reporting of the CHESS studies, 5, 6 discouraging the EPA from conducting their own epidemiological research. The National Institute of Environmental Health Sciences (NIEHS) began to take a larger role. Following the 1973 Arab oil embargo, Dr. David Rall, the Director of the NIEHS, invited proposals for a study of the health effects of air pollution associated with the anticipated switch from imported oil to domestically produced coal for electric generation in the United States. In response, Drs. Benjamin Ferris and Frank Speizer of the Harvard School of Public Health, proposed a prospective cohort study of the respiratory health effects of respirable particles and sulfur oxides on a sample of adults and children in six U.S. cities (Portage, WI; Topeka, KS; Watertown, MA; Kingston, TN; St. Louis, MO, and Steubenville, OH). The Harvard Six Cities Study was reviewed, approved and funded in 1974.

In 1979, the American Iron and Steel Institute commissioned the previously mentioned review of the existing epidemiologic literature on the health effects of particulate air pollution.1 The authors concluded that they could not "find any reasonable evidence that would justify" the US air quality standard for total suspended particulates. In a response in the following issue of the American Journal of Epidemiology, Dr. Carl Shy lambasted this review for consistently discounting epidemiologic studies showing associations while being uncritical of negative studies 7. Dr. James Ware and colleagues in a review commissioned by the EPA found that while there were only a limited number of epidemiologic studies, the evidence of increased mortality and morbidity associated with TSP was consistent with the EPA standards 8.

\section{Review of the EPA Particle Standard}

The Clean Air Act requires the EPA to periodically review the ambient air quality standard based on the latest scientific knowledge of health effects, but the epidemiology evidence remained limited. Nevertheless, in 1987 the EPA replaced the TSP standard with a standard for particles smaller than $10 \mu \mathrm{m}\left(\mathrm{PM}_{10}\right) .9$ This standard was based on dosimetric studies that had shown that particles larger than $\mathrm{PM}_{10}$ did not penetrate the body's defenses in the nose, mouth, and upper airways and were therefore unlikely to have respiratory effects. A handful of epidemiologic studies served as supporting evidence.10-12

The American Iron and Steel Institute challenged the 1987 standard, questioning whether any study could be used to support regulation unless the data underlying the studies were available to all affected parties. The courts upheld the use of these studies, 13 but this challenge to the scientific basis for the standard and the demand for access to primary data foreshadowed subsequent attempts to undermine the EPA air quality standards. 


\section{Time Series Studies}

In the 1980's analyses of counts of daily mortality in London had found inconsistent associations with concurrent particle (Black Smoke) measurements.14 Drs. Joel Schwartz and Allan Marcus reanalyzed the London daily mortality data using a time series approach. 15 These new analyses showed increased daily deaths associated with daily Black Smoke concentrations down to the lowest observed concentrations. However, because of the uniqueness of this approach, the different particle measuring methods between the U.K. and U.S., and other concerns with extrapolating the U.K. experience to the U.S., these results were discounted in the EPA review of the particle standard.

Time series analyses in the United States were limited because of the air pollution sampling methods. The gravimetric monitoring method for measuring airborne particle mass concentrations was very labor intensive, so monitoring only was required in a statistical sample of one day out of every six. This spotty data precluded precise examination of the daily effects of particles.

In 1991 Dr. Schwartz came to the Harvard School of Public Health on assignment from EPA. Hoping to replicate the London analyses in the United States, he sought sites with long records of daily measurements of airborne particulate levels. TSP was measured daily in Steubenville to provide timely indicators of episodes of high pollution. Counts of daily mortality there showed significant, positive associations with daily measures of TSP adjusting for season, trends, weather and other air pollutants 16 . In a follow-up analysis of daily TSP levels in Philadelphia, daily mortality also was found to be associated with particles, with specific associations with respiratory and cardiovascular deaths 17 . These time series studies of daily mortality and particulate air pollution demonstrated small but consistent epidemiologic associations between mortality and particle pollution at concentrations below the standards the EPA set to protect public health.

In the late 80 's, Dr. Arden Pope was investigating the effects of airborne emissions from a steel mill in Utah Valley. $\mathrm{PM}_{10}$ was measured daily because of frequent violations of the air quality standards. A strike had closed the mill for 13 months in 1986 and 1987, during which period Pope found both lower $\mathrm{PM}_{10}$ and lower respiratory hospital admissions in children.18 Analyses of daily mortality counts in Utah Valley found associations with $\mathrm{PM}_{10}$ similar to those found in Steubenville and Philadelphia,19 and showed a reduction in mortality during the steel mill strike.

Around this time, Dr. David Bates hypothesized that if air pollution was indeed associated with increased mortality, then it must also be associated with morbidities such as hospital admissions, emergency department visits, general practitioner visits, etc 20. It stood to reason that other health effects might be caused by exposure to particle pollution, such as asthma or bronchitic attacks, more respiratory symptoms, more asthma medication, lower lung function, etc. An examination of the air pollution epidemiologic literature showed just such a coherent and consistent pattern of related health effects in a range of epidemiologic studies internationally 21 .

Even as these new associations were being discovered though, questions were raised about the association between particulate pollution and public health. The epidemiologic data were not supported by experimental toxicological nor clinical data. And although time series methods were well developed in the econometric literature, the application of time series methods to epidemiologic data was new. A Colloquium on Particulate Air Pollution was held in Irvine, California in January 199422 which brought together a diverse set of 
approximately 200 researchers and regulators interested in the issues raised by the emerging particulate air pollution epidemiology.

At that meeting several industry-supported investigators presented analyses which directly challenged the results of the Steubenville and Philadelphia time series analyses.23,24, 25 They asserted that they could not reproduce the data, and that the reported associations might be artifacts of the particular statistical methods used, or might be due to incomplete statistical adjustment for the effects of weather factors or other air pollutants.

Conflicting claims regarding analyses of these publicly available datasets led to confusion and public squabbling. In 1994 the Health Effects Institute, an independent research agency funded equally by the EPA and the automobile industry to serve as a neutral reviewer of science having to do with motor vehicle emissions, stepped in to provide an objective evaluation of the daily time series studies. A team of scientists from Johns Hopkins School of Hygiene and Public Health, led by Drs. Jonathan Samet and Scott Zeger, were chosen to validate the Philadelphia, Utah, and other time-series studies. The Hopkins team reconstructed the data set for Philadelphia from original sources and confirmed the original results 26 . They also established the methodological validity of this approach.27, 28

This proved an important turning point. As time-series methods became better understood in the epidemiologic community, investigators began to replicate these results with publicly available daily air pollution, weather, and death data in other cities around the world. Within ten years more than a hundred time-series studies had been published in the peer reviewed literature. In fact, the editor of Epidemiology encouraged the authors of such air pollution papers to submit them to other journals.29

While replication of PM-mortality time series in different cities built the body of evidence about the connection between particulate pollution and morbidity and mortality, singly each paper did not lead to new insights. However, this body of evidence allowed the analysis of differences between cities. Meta-analyses suggested a specific association with fine particle $\mathrm{PM}_{2.5} .30$ Coordinated studies of multiple cities were organized. The APHEA (Air Pollution and Health: a European Approach) study was organized by Dr. Klea Katsouyannis across 10 cities in Europe 31. In the United States, the John Hopkins investigators led a pooled time series analysis across all the metropolitan areas in the United States, the National Morbidity and Mortality Air Pollution Study (NMMAPS).32, 33 These multi-city studies have not only provided pooled measures of association across these cities, but they have used the diversity of exposures and covariates to understand sources and effect modification, and have strengthened the analytic underpinnings of the time series approaches.

\section{Studies of Effects of Long-Term Particle Exposures}

While the epidemiologic evidence was strong for a causal link between episodically elevated particulate air pollution and daily mortality, the question remained whether these associations represented substantial life shortening and whether repeated or chronic exposures to elevated PM were associated with additional risks.

The prospective follow-up of the sample of adults in the Harvard Six Cities study provided an opportunity to examine survival associated with city-specific mean air pollution concentrations adjusting for individual risk factors. While the sample was small (8411 individuals) and the follow-up period was short (11 to 14 years), there were surprisingly strong and highly statistically significant associations between reduced survival and community average fine particle $\left(\mathrm{PM}_{2.5}\right)$ concentrations. After adjusting for individual risk factors, life expectancy was estimated to be reduced by approximately two years in the dirtiest city compared to the cleanest, although a linear relationship was seen across all six 
cities. To put this in context, eradicating all cancer in the United States had been estimated to increase average life expectancy by two years.34 If true, community air pollution in the United States, in cities which met the current EPA ambient air quality standard to protect the public health, had substantial effects on life expectancy.

With such dramatic findings, the investigators felt they had to replicate these results before submitting them for publication. But how do you replicate a prospective cohort study that had been underway for more than 15 years. Dr. Frank Speizer suggested examining other prospective cohort studies with samples of adults distributed across the United States. In 1982, the American Cancer Society (ACS) had enrolled a cohort of approximately 1.2 million men and women across the United States in the Cancer Prevention Study II (CPS-II) 35 to study the impact of environmental and lifestyle factors on cancer etiology in a large group of American men and women. We proposed to match CPS II participants with EPA monitored $\mathrm{PM}_{2.5}$ data based on their address (zip code). This would allow a specific test of the hypothesis developed in the Six Cities study analyses that life expectancy was causally related to community mean fine particle air pollution concentrations.

The American Cancer Society investigators agreed, and Dr. Arden Pope, who was at Harvard on sabbatical, merged previously compiled data from a special EPA monitoring program of $\mathrm{PM}_{2.5}$ in a sample of U.S. cities 36 with the CPS II mortality follow-up data. The analyses of these combined data sets confirmed the results of the Six Cities analyses in a sample of more than 500,000 US adults. With this replication in an independent cohort, the Six Cities 37 and the American Cancer Society results 38 were each submitted and published in high visibility medicine journals.

\section{EPA Forced to Act}

The Clean Air Act requires that the standards be reviewed every five years to reflect the latest scientific knowledge. The EPA last had reviewed the particle standard in 1987. Based on the epidemiologic evidence from the time-series and prospective cohort studies that appeared in the early 1990s, the American Lung Association sued EPA in federal court in 1994 to force the agency to review the $\mathrm{PM}_{10}$ standard.39 The court ordered the EPA Administrator to review the particle air quality standard by January 1997.

The EPA review drew particular attention to the epidemiologic evidence Though the EPA cited more than a hundred epidemiologic studies in their review, the debate focused on the two prospective cohort studies showing increased mortality effects.40 Critics argued that there was a lack of supporting evidence from other disciplines, specifically clinical and animal/cellular studies, which led to calls for a delay while additional research was undertaken.41, 42 It was suggested that the epidemiologic findings could be explained by alternative individual or community confounders not considered in the original analyses, or that the results were sensitive to specific analytic methods. 43 There were concerns that the key studies had been produced by a small group of investigators. The validity of the underlying data was questioned. There were calls from political leaders, industry representatives, interested scientists, and others to make the data available for further scrutiny and analyses, the issue of openness that had been raised years before.

The investigators who collected the original data argued that there were constraints on the dissemination of confidential information, as well as concerns about the intellectual property rights. Release of original data would violate the assurances of confidentiality that had been given to participants and to state and national agencies who provided the individual data.

Given the specific interest in the Six Cities and American Cancer Society studies, the investigators of these two cohort studies approached the Health Effects Institute to serve 
once again as an objective arbiter. HEI undertook an open search for individual investigators to conduct 1) a quality assurance audit of the data, 2) a replication and validation of the originally reported results, and 3) sensitivity analyses to evaluate the robustness of the original findings to alternative analytic methods and inclusion of additional potential confounders, all with appropriate controls for confidentiality and multiple layers of oversight.

In 2000, the HEI team of 32 investigators, led by Dr. Daniel Krewski of the University of Ottawa, published a 297 page report 44 which found that the data were "generally of high quality" and that the results originally reported could be reproduced and validated $45^{-} 47$. The reanalysis demonstrated the robustness of the PM-mortality risk estimates to many alternative model specifications. The re-analyis team also made a number of innovative methodological contributions that not only demonstrated the robustness of the PM-mortality results, but substantially contributed to subsequent analyses.

While the HEI reanalysis may be considered a model for how controversial science can be addressed, the results of this independent evaluation did not satisfy many in industry. Senator Richard Shelby of Alabama inserted language into the federal budget which called for changes in the rules for federal funding of research conducted at "institutions of higher education, hospitals, and other non-profit organizations", such that any research funded by federal grants would be subject to the Freedom of Information Act if that research was cited in federal rule-making. This legislation, commonly known as the Shelby Amendment, was inserted at the request of industries that had been unable to obtain access to the data underlying the particulate-matter studies.

\section{Decision and Subsequent Research}

In the meantime, the review of the particle standard required by the court, continued and in 1997 the EPA promulgated a new standard for $\mathrm{PM}_{2.5}$ 48. The decision to regulate $\mathrm{PM}_{2.5}$ was still based largely on the epidemiologic evidence. As part of that decision, the EPA asked the National Research Council to convene a panel to evaluate the research needs in other fields of science such as toxicology to more fully understand particulate air pollution exposures and health effects. As a result approximately $\$ 450$ million has been devoted to particulate air pollution research over the last decade. This research effort has led to major advances in understanding of the mechanisms of particle effects, and understanding of the determinants of $\mathrm{PM}_{2.5}$ exposures in the general population.49-51

Extended analyses of the American Cancer Society cohort have provided insights into the specific effects of particulate pollution on particular subpopulations. 52-55 Epidemiologic analyses of other cohorts have replicated and expanded upon the results of the Six Cities and American Cancer Society cohorts 56-60. Continued follow-up of the Harvard Six-Cities cohort has shown that reductions in $\mathrm{PM}_{2.5}$ concentrations are associated with reduced mortality risk,61 suggesting that the mortality effects of long-term air pollution may be at least partially reversible. An examination of county-specific life-expectancy in 50 metropolitan areas across the United States showed that reductions in average $\mathrm{PM}_{2.5}$ concentrations between 1980 and 2000 has led to measurable increases in average life expectancy. 62

Nevertheless, the 1997 decision to regulate $\mathrm{PM}_{2.5}$ remains controversial.63, 64 In 2006, the EPA Administrator lowered the short-term $\mathrm{PM}_{2.5}$ ambient air quality standard, but ignored the recommendation by the EPA's external Clean Air Science Advisory Committee to lower the long-term standard. 65 


\section{Lessons}

Epidemiology played a key role in identifying a major threat to public health, and provided key information that led to standards for particulate pollution that are having a substantial beneficial effect on public well being. Vested interests fought those standards by attacking the epidemiologic evidence in general and specific key studies. Ultimately those attacks failed, but they delayed regulations that would have provided greater health protection for the public. Many public health issues play out this way, so the lessons offered here are important.

The epidemiology prevailed in this instance for several reasons;

- The epidemiologic body of work - the breadth and consistency of the evidence was strong.

- The scientific work itself was carefully done, thorough, replicable, and able to withstand scrutiny detailed and extensive review and validation.

- The scientists doing the work participated in the public policy debate as scientists supporting their findings,.

As public health professionals, epidemiologists are in a strong position to advocate for public health policies, but at the risk of compromising their perceived scientific objectivity. This case demonstrates that this objectivity gives scientists and their evidence the influence to shape policy.

When issues being investigated scientifically become matters of public controversy, the normal process of replication and validation of hypotheses will move from a scientific setting into a political and media setting. Advocates for and against a particular viewpoint will selectively use epidemiologic data to advance their positions. Many scientists rightly worry that public and media discussion of their work will involve inaccuracies, simplifications, misunderstandings, overstatements, and assumptions about their work, and therefore do not participate in the political and media controversies that arise over their work. This case speaks to the importance of the scientific voice as part of the public debate over important public health policy.

The role of HEI as a credible neutral arbiter of scientific controversy was important.9 But reanalysis and validation of existing findings can only do so much. True replication requires not reanalyzing existing work but independent investigators producing independent data. The HEI process made important contributions in evaluating, advancing, and applying new methods which led to significant additional analyses. But the HEI work reanalyzing an existing body of evidence was time-consuming and expensive. It would not be a good use of resources to require this approach for all studies contributing to the regulatory actions, or even to a few key studies.

Unfettered science is the best way to serve public health. But to hope for such a clear road is optimistic. Vested interests - economic, political, consumer - will frequently force controversy about and intense scrutiny of key studies. Nevertheless, the importance of solid epidemiology, and of scientists willing to support their work in the public arena, cannot be overstated. In this case, the work itself, and the people doing that work, made a profound contribution to public health.

\section{Acknowledgments}

Preparation of this paper was supported in part by NIEHS Environmental Health Center Grant (ES-00002) and by the Environmental Protection Agency (STAR grant RD832416). It has not been subjected to EPA's required peer 
and policy review and therefore does not necessarily reflect the views of the Agency and no official endorsement should be inferred. David P. Ropeik provided editorial assistance.

\section{Bibliography}

1. Holland WW, Bennett AE, Cameron IR, et al. Health effects of particulate pollution: reappraising the evidence. Am J Epidemiol. 1979; 110:527-659. [PubMed: 517497]

2. 2006 National Ambient Air Quality Standards for Particle Pollution. 2006. Accessed at http://www.epa.gov/ttn/ecas/regdata/RIAs/Executive\%20Summary.pdf

3. Office of Management and Budget. , editor. Office of Information and Regulatory Affairs. Report to Congress on the Benefits and Costs of Federal Regulations and Unfunded Mandates on State, Local, and Tribal Entities. Washington, DC: 2007. 2007

4. National Air Pollution Control Adminstration., editor. U.S. Department of Health Education and Welfare. Air Quality Criteria for Particulate Matter. U.S. GPO; 1969.

5. Report on Joint Hearings on the Conduct of the Environmental Protection Agency's Comuniyt Health and Environment Surveillance System (CHESS) Studies. Washington, DC: 1976 April 9. 1976

6. Brown, BE. The Environmental Protection Agency's Research Program with primary emphasis on the Community Health and Environmental Surveillance System (CHESS): an investigative report. Washington, DC: US GPO; 1976.

7. Shy CM, Muller KE. Evaluating the effects of air pollution on sensitive subjects. Am J Public Health. 1980; 70:680-1. [PubMed: 7386700]

8. Ware JH, Thibodeau LA, Speizer FE, Colome S, Ferris BG Jr. Assessment of the health effects of atmospheric sulfur oxides and particulate matter: evidence from observational studies. Environ Health Perspect. 1981; 41:255-76. [PubMed: 6977444]

9. Greenbaum DS, Bachmann JD, Krewski D, Samet JM, White R, Wyzga RE. Particulate air pollution standards and morbidity and mortality: case study. Am J Epidemiol. 2001; 154:S78-90. [PubMed: 11744533]

10. Dassen W, Brunekreef B, Hoek G, et al. Decline in children's pulmonary function during an air pollution episode. J Air Pollut Control Assoc. 1986; 36:1223-7. [PubMed: 3794084]

11. Dockery DW, Ware JH, Ferris BG Jr, Speizer FE, Cook NR, Herman SM. Change in pulmonary function in children associated with air pollution episodes. J Air Pollut Control Assoc. 1982; 32:937-42. [PubMed: 7130539]

12. Ware JH, Ferris BG Jr, Dockery DW, Spengler JD, Stram DO, Speizer FE. Effects of ambient sulfur oxides and suspended particles on respiratory health of preadolescent children. Am Rev Respir Dis. 1986; 133:834-42. [PubMed: 3706894]

13. Natural Resources Defense Council, Inc. v. Administrator, US EPA. DC Cir. 1990

14. Mazumdar S, Schimmel H, Higgins IT. Relation of daily mortality to air pollution: an analysis of 14 London winters, 1958/59-1971/72. Arch Environ Health. 1982; 37:213-20. [PubMed: 7114901]

15. Schwartz J, Marcus A. Mortality and air pollution in London: a time series analysis. Am J Epidemiol. 1990; 131:185-94. [PubMed: 2403468]

16. Schwartz J, Dockery DW. Particulate air pollution and daily mortality in Steubenville, Ohio. Am J Epidemiol. 1992; 135:12-9. discussion 20-5. [PubMed: 1736656]

17. Schwartz J, Dockery DW. Increased mortality in Philadelphia associated with daily air pollution concentrations. Am Rev Respir Dis. 1992; 145:600-4. [PubMed: 1546841]

18. Pope CA 3rd. Respiratory disease associated with community air pollution and a steel mill, Utah Valley. Am J Public Health. 1989; 79:623-8. [PubMed: 2495741]

19. Pope CA 3rd, Schwartz J, Ransom MR. Daily mortality and PM10 pollution in Utah Valley. Arch Environ Health. 1992; 47:211-7. [PubMed: 1596104]

20. Bates DV. Health indices of the adverse effects of air pollution: the question of coherence. Environ Res. 1992; 59:336-49. [PubMed: 1464287]

21. Dockery DW, Pope CA 3rd. Acute respiratory effects of particulate air pollution. Annu Rev Public Health. 1994; 15:107-32. [PubMed: 8054077] 
22. Phalen RF, McClellan RO. PM10 Reaserch Needs. Inhalation Toxicology. 1995; 7:773-9.

23. Li Y, Roth HD. Daily mortality analysis by using different regression models in Philadelphia County, 1973-1990. Inhalation Toxicol. 1995; 7:45-58.

24. Moolgavkar SH, Luebeck EG, Hall TA, Anderson EL. Particulate Air Pollution, Sulfur Dioxide, and Daily Mortality: A Reanalysis of the Steubenville Data. Inhalation Toxicology. 1995:7.

25. Moolgavkar SH, Luebeck EG, Hall TA, Anderson EL. Air pollution and daily mortality in Philadelphia. Epidemiology. 1995; 6:476-84. [PubMed: 8562622]

26. Kelsall JE, Samet JM, Zeger SL, Xu J. Air pollution and mortality in Philadelphia, 1974-1988. Am J Epidemiol. 1997; 146:750-62. [PubMed: 9366623]

27. Samet JM, Dominici F, Zeger SL, Schwartz J, Dockery DW. The National Morbidity, Mortality, and Air Pollution Study. Part I: Methods and methodologic issues. Res Rep Health Eff Inst. 2000:5-14. discussion 75-84.

28. Samet JM, Zeger SL, Dominici F, et al. The National Morbidity, Mortality, and Air Pollution Study. Part II: Morbidity and mortality from air pollution in the United States. Res Rep Health Eff Inst. 2000; 94:5-70. discussion 1-9.

29. Samet JM. Air pollution and Epidemiology: “deja vu all over again?”. Epidemiology. 2002; 13:118-9. [PubMed: 11880748]

30. Levy JI, Hammitt JK, Spengler JD. Estimating the mortality impacts of particulate matter: what can be learned from between-study variability? Environ Health Perspect. 2000; 108:109-17. [PubMed: 10656850]

31. Zmirou D, Schwartz J, Saez M, et al. Time-series analysis of air pollution and cause-specific mortality. Epidemiology. 1998; 9:495-503. [PubMed: 9730027]

32. Samet JM, Dominici F, Curriero FC, Coursac I, Zeger SL. Fine particulate air pollution and mortality in 20 U.S. cities, 1987-1994. N Engl J Med. 2000; 343:1742-9. [PubMed: 11114312]

33. Dominici F, McDermott A, Daniels M, Zeger SL, Samet JM. Revised analyses of the National Morbidity, Mortality, and Air Pollution Study: mortality among residents of 90 cities. J Toxicol Environ Health A. 2005; 68:1071-92. [PubMed: 16024489]

34. Cairns, J. Cancer: Science and Society. San Francisco: W.H. Freeman and Co; 1978.

35. Garfinkel L, Heath CW. Cancer Prevention Study II - The American Cancer Society Prospective Study. 5 B Statistical Bulletin. 1992; 73:21-8.

36. Ozkaynak H, Thurston GD. Associations between 1980 U.S. mortality rates and alternative measures of airborne particle concentration. Risk Anal. 1987; 7:449-61. [PubMed: 3444932]

37. Dockery DW, Pope CA 3rd, Xu X, et al. An association between air pollution and mortality in six U.S. cities. N Engl J Med. 1993; 329:1753-9. [PubMed: 8179653]

38. Pope CA 3rd, Thun MJ, Namboodiri MM, et al. Particulate air pollution as a predictor of mortality in a prospective study of U.S. adults. Am J Respir Crit Care Med. 1995; 151:669-74. [PubMed: 7881654]

39. American Lung Association v. Browner. CIV-93-643-TUC-ACM: D Ariz. 1994

40. Kaiser J. Showdown over clean air science. Science. 1997; 277:466-9. [PubMed: 9254414]

41. Madia WJ. A call for more science in EPA regulations. Science. 1998; 282:45. [PubMed: 9786793]

42. McClellan, RO.; Miller, FJ. An Overview of EPA's Proposed Revision of the Particualte Matter Standard. Research Triangle Park, NC: Chemical Industry Institute of Toxicology; 1997.

43. Moolgavkar SH. Air pollution and mortality. N Engl J Med. 1994; 330:1237-8. [PubMed: 8139642]

44. Krewski, D.; Burnett, RT.; Goldberg, MS., et al. Reanalysis of the Harvard Six Cities Study and teh American Cancer Society Study of Particualte Air Pollution and Mortality. Cambridge, MA: Health Effects Institute; 2000.

45. Krewski D, Burnett RT, Goldberg MS, et al. Validation of the Harvard Six Cities Study of particulate air pollution and mortality. N Engl J Med. 2004; 350:198-9. [PubMed: 14711928]

46. Kaiser J. Air pollution. Panel backs EPA and 'ix cities' study. Science. 2000; 289:711. [PubMed: 10950710] 
47. Krewski D, Burnett RT, Goldberg MS, et al. Overview of the reanalysis of the Harvard Six Cities Study and American Cancer Society Study of Particulate Air Pollution and Mortality. J Toxicol Environ Health A. 2003; 66:1507-51. [PubMed: 12959828]

48. US Environmental Protection Agency. 40 CFR Part 50, National Ambient Air Quality Standards for Particulate Matter; Final Rule. Federal Register. 1997; 62:38651-701.

49. Lippmann M, Frampton M, Schwartz J, et al. The U.S. Environmental Protection Agency Particulate Matter Health Effects Research Centers Program: a midcourse report of status, progress, and plans. Environ Health Perspect. 2003; 111:1074-92. [PubMed: 12826479]

50. Committee on Research Priorities for Airborne Particulate Matter, National Research Council. Early Research Progress. Washington, DC: National Academy Press; 2001. Research Priorities for Airborne Particulate Matter: III.

51. Committee on Research Priorities for Airborne Particulate Matter, National Research Council. Continuing Research Progress. Washington, DC: National Academy Press; 2004. Research Priorities for Airborne Particulate Matter: IV.

52. Pope CA 3rd, Burnett RT, Thurston GD, et al. Cardiovascular mortality and long-term exposure to particulate air pollution: epidemiological evidence of general pathophysiological pathways of disease. Circulation. 2004; 109:71-7. [PubMed: 14676145]

53. Pope CA 3rd, Burnett RT, Thun MJ, et al. Lung cancer, cardiopulmonary mortality, and long-term exposure to fine particulate air pollution. Jama. 2002; 287:1132-41. [PubMed: 11879110]

54. Krewski D, Burnett R, Jerrett M, et al. Mortality and long-term exposure to ambient air pollution: ongoing analyses based on the American Cancer Society cohort. J Toxicol Environ Health A. 2005; 68:1093-109. [PubMed: 16024490]

55. Jerrett M, Burnett RT, Ma R, et al. Spatial analysis of air pollution and mortality in Los Angeles. Epidemiology. 2005; 16:727-36. [PubMed: 16222161]

56. Hoek G, Brunekreef B, Goldbohm S, Fischer P, van den Brandt PA. Association between mortality and indicators of traffic-related air pollution in the Netherlands: a cohort study. Lancet. 2002; 360:1203-9. [PubMed: 12401246]

57. Miller KA, Siscovick DS, Sheppard L, et al. Long-term exposure to air pollution and incidence of cardiovascular events in women. N Engl J Med. 2007; 356:447-58. [PubMed: 17267905]

58. Lipfert FW, Baty JD, Miller JP, Wyzga RE. PM2.5 constituents and related air quality variables as predictors of survival in a cohort of U.S. military veterans. Inhal Toxicol. 2006; 18:645-57. [PubMed: 16864555]

59. Filleul L, Rondeau V, Vandentorren S, et al. Twenty five year mortality and air pollution: results from the French PAARC survey. Occup Environ Med. 2005; 62:453-60. [PubMed: 15961621]

60. Enstrom JE. Fine particulate air pollution and total mortality among elderly Californians, 1973-2002. Inhal Toxicol. 2005; 17:803-16. [PubMed: 16282158]

61. Laden F, Schwartz J, Speizer FE, Dockery DW. Reduction in fine particulate air pollution and mortality: Extended follow-up of the Harvard Six Cities study. Am J Respir Crit Care Med. 2006; 173:667-72. [PubMed: 16424447]

62. Pope CA 3rd, Ezzati M, Dockery DW. Fine-Particulate Air Pollution and Life Expectancy in the United States. New England Journal of Medicine. 2009 In Press.

63. Kaiser J. Air pollution. Evidence mounts that tiny particles can kill. Science. 2000; 289:22-3. [PubMed: 10928919]

64. Kaiser J. Epidemiology. Mounting evidence indicts fine-particle pollution. Science. 2005; 307:1858-61.

65. Stokstad E. EPA Tightens Some Soot Standards. ScienceNOW. September 21.2006 2006. 